\title{
Škola a sociální pomoc ve druhé polovině 19. století
}

\author{
Martina HALÍřovÁ
}

\author{
ARTICLE INFO \\ Article history: \\ Received 25 March 2020 \\ Accepted 1 May 2020 \\ Available online 31 \\ December 2020 \\ Keywords: \\ school, social assistance, \\ protection of children and \\ youth, charitable \\ activities, funds and \\ foundations, $19^{\text {th }}$ century

\begin{tabular}{l}
\hline M. Halíŕová \\
Národní pedagogické \\
muzeum a knihovna J. A. \\
Komenského $\bullet$ \\
Valdštejnská $161 / 20$ \\
11800 Praha $1 ・$ \\
Česká republika • \\
halirova@ @npmk.cz
\end{tabular}

\begin{abstract}
School and a social assistance in the second half of the $19^{\text {th }}$ century

The paper deals with the forms of social assistance provided to poor children and youth in schools. The specific examples are illustrated by the example of Pardubice town. The article mainly deals with the second half of the $19^{\text {th }}$ century, when under the influence of social changes the charitable activities aimed at children and young people were developed. The article mentions also the end of the $18^{\text {th }}$ century, when education and social care reforms took place, and influenced the development of social assistance in the following century.

Two types of institutions were established at schools; on one hand, associations providing financial or material support, on the other, groups providing out-of-school activities for children and youth. These organizations had the same goal - the discipline of the poor in society.
\end{abstract}

\section{Úvod}

Dějiny školství a dějiny sociální péče jsou v současnosti oblíbeným tématem. Svědčí o tom řada knih a studií (např. Morkes, 2004; Kasper a Pánková, 2015; Hlavačka, 2015). Dosud zůstala neprobádána otázka, zda na školách byla sociální pomoc uskutečňována a jakým způsobem byla vykonávána. $V$ př́spěvku se zaměříme především na druhou polovinu 19. století, a to až do roku 1914, přičemž v krátkosti zmíníme i konec 18. století, kdy započaly změny týkající se sociální péče a školství. První světová válka vyhrotila většinu problémů a školy musely čelit náporu propagandy a válečných úkonů (Lenderová, Halírová, Jiránek, 2015). Cílem studie je zmapovat především péči o děti školou povinné, tedy o děti ve věku 614 let. Jelikož dobročinné spolky fungovaly i při středních školách, budou zmíněny i formy pomoci zaměřené na mládež ve věku 14-18 let. Konkrétní př́klady sociální pomoci organizované při škole jsou představeny na př́íkladu města Pardubice.

Počátky rozvoje školství a sociálního zákonodárství je možné vysledovat $\mathrm{v}$ době vlády Marie Terezie a Josefa II. Součástí reforem byla změna školství a péče o obyvatelstvo. Školní vzdělávání se týkalo všech sociálních vrstev, základní školy byly určeny pro každého bez rozdílu pohlaví a stavu. Školská povinnost přivedla do lavic i děti, jejichž rodiče považovali školu za zbytečnou (Lenderová a Rýdl, 2006, s. 179). Reformátoři si tuto nevoli uvědomovali, 
a proto zavedli dozor nad školami a plněním docházky. Zároveň chudí rodiče byli osvobozeni od školného a jejich děti dostávaly potřebné učebnice zdarma (Šafránek, 1897, s. 54).

Vzdělání bylo považováno za dobrodiní poskytované státem, které vede k „blaženosti“ všech členů společnosti (Novotný, 2008, s. 148an). Cílem vzdělávání a výchovy se stalo dosažení blaha, důležitá byla mravnost a ctnost. Prostřednictvím výchovy se mělo otevř́ít srdce vychovávaného vůči neštěstí a potřebám druhých (Kasper, 2015, s. 78-79). Vzdělání mělo vést člověka $\mathrm{k}$ pracovitosti, šetrnosti a stř́́dmosti, tyto ctnosti byly vnímány jako preventivní prostředky vůči chudobě (Tamtéž, s. 81). Cílem školního vzdělání bylo uplatnění každého jednotlivce ve společnosti. Představovalo výrazný disciplinační prvek zaměřený na nižší vrstvy společnosti (Bělina, Kaše a Kučera, 2001, s. 259an.).

Vnímání chudoby a prostředky pro boj s ní se proměňovaly v čase. Od 18. století začala být chudoba chápána jako zdroj většiny ohrožujících jevů, které nejvíce mohly zasáhnout právě nezletilého jedince a mohly se stát př́činou „,nešt’astného“ života v dospělosti. Pojem chudoby závisel na stanovení vlastnictví a určení výše prostředků potřebných k životu - jako chudý byl vnímán pouze ten, který neměl nikoho, kdo by ho mohl podpořit - tj. rodiče nebo př́buzné. Chudoba dítěte byla odvozována od nemajetnosti rodičů. Dítě samo o sobě bylo do statistik a výkazů zahrnuto pouze tehdy, když nemělo nikoho, kdo by se o něj postaral, a po rodičích nezdědilo žádný majetek. Chudé dítě bylo znevýhodněno v mnoha oblastech života - jeho dětství bylo kratší, úroveň péče závisela na vůli a času rodičů nebo pěstounů či poručníka, byla o něco horší než v movitějších rodinách - především co se týká kvality stravy, vzdělání, oblečení a zdravotní péče. V očích pedagogů a filantropů figurovala chudoba jako faktor, který negativně působí při výchově (Halířová, 2012, s. 35). Proto byly hledány prostředky, jak s chudobou bojovat. Jedním z nich bylo zakládání industriálních škol, které měly vést děti $\mathrm{k}$ pilné práci. Výuka se skládala $\mathrm{z}$ textilní výroby, pletení, šití, zemědělských prací, péče o ovocné stromy i včelaření. Žáci měli být vybaveni vědomostmi a schopnostmi, které vedly k uplatnění ve společnosti, aby se nemuseli v budoucnosti spoléhat na almužnu (Kasper, 2015, s. 81).

Úkolem školy nebyla sociální péče o děti - hlavním organizátorem podpůrné činnosti v podobě sbírek pro chudé byla církev, vrchnost či movití jednotlivci. Veřejná sociální péče byla $\mathrm{v}$ této době omezená, nebot' se spoléhalo především na institut rodiny. Od konce 18. století začaly být povinnosti péče o potřebné stále více delegovány na domovské obce. Péče byla zaměřena na úplné sirotky nebo děti bez rodiny, postupem doby byla rozšiřována na nemajetné děti. Její kvalita souvisela se sociálním původem dítěte (Halírová 2012, s. 40an.). Finanční podpora měla být vyplácena pouze těm, kteří si ji zasloužili. Zároveň začaly vznikat specializované ústavy zaměřené na péči o nemocné a postižené. Učitelé $v$ této době do sociální péče prŕliš nezasahovali, nebot' se sami nacházeli ve špatné ekonomické situaci (Brezinka, 2015, s. 38). Zároveň prestiž povolání byla nízká a neexistovala možnost kariérního postupu (Grimm, 2015, s. 58).

Školní výchova a vzdělávání nemohlo samo vyřešit sociální otázku a boj s chudobou, situaci navíc zhoršila průmyslová revoluce a růst měst. Chudé dítě bylo více vtahováno do námezdního pracovního procesu. Výdělečná práce neměla zároveň představovat překážku pro 
vzdělávání. S postupem industrializace můžeme sledovat i nárůst dobročinných snah zaměřených na podporu chudých dětí a vznik nových institucí věnujících se péči o ně. Snahou filantropů a dobročinné péče bylo nahradit chybějící prvky, tedy sociální zabezpečení.

Změnu do podoby školy a př́stupu k sociální péči přineslo politické uvolnění v 60. letech 19. století. V roce 1863 vstoupil v platnost domovský zákon, který jako základní jednotku sociální péče určil domovskou obec. Každá domovská obec se musela postarat o svého člena. Domovskou př́slušnost bylo možné získat pouze narozením, sňatkem, získáním veřejného úřadu nebo přijetím do domovského svazku. Další změnu v oblasti sociální péče přinesl spolčovací zákon, který umožnil vznik spolků. Některé vznikaly před vydáním tohoto zákona. Řada nových spolků se zaměřila na péči o sociálně slabé děti a dobročinnost (Halírová, 2012, s. 156).

Šedesátá léta znamenala uvolnění i pro školství, které bylo dosud svázáno církevním dozorem. Hasnerův zákon vydaný roku 1869 přinesl nejen rozvoj vzdělávání učitelů, ale i růst sociální prestiže povolání, což bylo umožněno začleněním profese jako veřejné služby. Z učitelů a učitelek se stali státní úředníci se stálým ročním platem (Grimm, 2015, s. 58). V této době se začali učitelé a učitelky angažovat, což vyústilo v zakládání učitelských spolků (Tamtéž, s. 64). Kromě profesních spolků byli vyučující aktivní i ve spolcích osvětových, muzejních či těch zabývajících se sociální péčí o děti a mládež.

Škola jako taková nebyla ze zákona nositelkou sociální pomoci. Jediné, čeho mohli chudí rodiče dosáhnout, bylo odpuštění placení školného a poskytnutí učebnic zdarma. Sociální pomoc po celé devatenácté století poskytovala domovská obec. Od šedesátých let 19. století můžeme sledovat vznik řady dobročinných spolků zaměřených na péči o děti a mládež. V letech 1867-1918 bylo v Čechách a na Moravě na základě spolkového zákona založeno 1142 dobročinných spolků, z nichž bylo 839, tedy 73,5 \%, zaměřeno na péči o děti a mládež. Ostatních 393 spolků se věnovalo všeobecné dobročinné péči (Tvrdoň a Zeman, 1931, s. 36). Zároveň většina obecních zastupitelstev přispívala dobročinným spolkům působícím na jejich území.

Spolky zabývající se podporou a ochranou dětí a mládeže se zaměřily na zdraví a vzdělávání dětí - zřizovaly polévkové ústavy, podporovaly chudé školní děti, kterým poskytovaly oblečení, školní pomůcky a stravu. Studujícím středních škol hradily i náklady na ubytování v místě školy a posílaly je v letních měsících na zkušenou. ${ }^{1}$ Vznikaly spolky financující a provozující prázdninové kolonie určené pro děti z měst nebo spolky pro zrízení a financování sirotčinců, mateřských škol a jeslí. Zakládány byly také spolky provozující azyly pro sirotky či spolky zaměřující se na šestinedělky, jejichž účelem bylo pečovat o chudou matku po narození dítěte, poskytovat jí stravu a potřebné prádlo (Lenderová a Rýdl, 2006, s. 166-167). Péče byla většinou určena dětem a mládeži od nejranějšího věku do dvaceti let. V roce 1902 provedla Zemská statistická kancelář dotazníkový výzkum, při kterém zjišt'ovala počet chudých osiřelých, opuštěných a mravně ohrožených dětí do osmnácti

\footnotetext{
${ }^{1}$ Spolek pro podporu nemajetných studujících reálné školy v Pardubicích, 1914. Zpráva o činnosti. Okresní úřad Pardubice (dále OÚ Pardubice), kart. 489, inv. č. 781. Státní okresní archiv Pardubice (dále SOkA Pardubice).
} 
let. Bylo zjištěno, že ve věku školou povinném je 13861 chudých chlapců a 13057 dívek (Engliš, 1908, s. 94). Dobročinná péče tak mohla pomoci pouze zlomku potřebných.

Z velkého množství existujících dobročinných spolků se zaměříme pouze na ty, které fungovaly při školách, byly určeny pro děti navštěvující konkrétní školu. V těchto případech se setkáme se dvěma typy péče, a to s materiální či finanční podporou a se vznikem institucí, které na děti dohlížely a organizovaly pro ně mimoškolní činnosti.

\section{Materiální a finanční podpora chudých dětí}

Při městských a obecných školách nejčastěji vznikaly spolky zaměřené na podporu nemajetných žáků. V roce 1906 fungovalo na území Čech 343 těchto spolků. Žáci a žákyně byli většinou podporováni bez rozdílu jejich náboženského vyznání. Důležitá byla domovská př́slušnost ke školní obci. Spolky neposkytovaly peníze dětem přímo, naopak pro ně nakupovaly oděvy, obuv a školní potřeby. Některé spolky pořádaly pro děti vánoční nadílky (Engliš, 1908, s. 101).

Významným spolkem podpůrného charakteru se stal Krejcarový spolek, později Korunový či Haléřový spolek (existovala i německá varianta). Tento spolek nalezneme téměř v každém městě, a to jak v Čechách, tak na Moravě. K roku 1906 jich fungovalo v Čechách 239. Spolkem obdobného charakteru byl Spolek Přátel / Přítel mládeže. Jeho cílem byla nejen podpora chudých dětí, ale i snaha o navázání lepší spolupráce mezi školou a rodinou. Vznikaly spolky i ryze dámského charakteru, ty většinou darovaly dětem šatstvo, organizovaly pro ně besídky a vánoční nadílky, případně zřizovaly výchovné ústavy pro nejmenší (Engliš, 1908, s. 101).

Novým fenoménem, který se v českých zemích objevil, byly tzv. polévkové ústavy. Setkáváme se s nimi od 70. let 19. století (Št’astná, 1977, s. 18-19). Úkolem ústavů bylo „podílet chudé, zejména přespolní děti v zimních měsících výživnou polévkou“ (Engliš, 1908, s. 100). Podmínkou pro poskytnutí oběda zdarma byla chudoba. Podmínky některých polévkových ústavů byly př́snější - aby si dítě zasloužilo porci, muselo být mravné a pilné. Všechny polévkové ústavy zaměřené na školní mládež fungovaly omezenou dobu, většinou v zimních měsících, bývaly otevřeny od října do března. Jejich cílem bylo upevnit zdraví chudých dětí a zajistit jim alespoň jedno vydatné jídlo v nejrizikovějších měsících. Poskytnutím stravy měla být i podporována docházka chudých dětí do školy. Jídlo bylo rozdáváno vždy v poledne, většinou se skládalo z polévky a housky či chleba. Pokud to finanční prostředky spolku umožňovaly, mohlo dítě dostat i brambory nebo buchtu. Náklady na uvaření jedné polévky se pohybovaly mezi 3-8 haléři. Polévku vařily bud' členky spolku, nebo manželka řídícího učitele. Podle statistických údajů existovalo v Čechách v letech 18811890 celkem 6 polévkových ústavů, v letech 1891-1900 jich bylo 15, 1901-1908 se zvýšil jejich počet na 64 (Engliš, 1908, s. 100).

Kromě škol zřizovaly polévkové ústavy i obce - obecní polévkové ústavy se nacházely většinou ve městech nad 5000 obyvatel, některé z nich byly zaměřeny pouze na školní mládež. Např. v roce 1890 vznikl obecní polévkový ústav v Karlíně, který v roce 1905 školním dětem poskytl 36153 porcí. Na začátku 20. století měly některé školy už vlastní kuchyně (Engliš, 1908, s. 101). Jídlo chudým dětem rozdávaly i spolky zaměřené na 
dobročinnost. ${ }^{2}$ Podle zpráv zemské školní rady fungovalo při školních obcích v roce 1907 celkem 1808 polévkových ústavů zaměřených na pomoc školním dětem (Engliš, 1908, s. 101).

Kromě podpůrných a stravovacích spolků vznikaly při středních a vysokých školách stipendijní spolky. Ty se po celé 19 . století zaměřovaly na podporu chudých a nadaných chlapců. Kromě chudoby, důležitého kritéria pro poskytnutí pomoci, byl podstatný prospěch a mravnost daného žáka. Nadaným nemajetným studentům spolek platil byt nebo stravu, poskytoval bezplatně knihy, učební pomůcky a papír, žáci však museli učebnice a školní potřeby po uplynutí školního roku vrátit. Pokud student onemocněl, spolek mu zajistil ošetření a léčbu, rovněž v př́padě potřeby zajišt'oval nadaným studentům i ošacení a obuv. Některé spolky dokonce vysílaly své svěřence v létě na zkušenou do průmyslových oblastí, studující byl povinen o sesbíraných zkušenostech napsat referát. Po návratu musel tuto práci předložit řediteli školy, který ji prezentoval na začátku školního roku učitelskému sboru a přečetl ve vyšších třídách. ${ }^{3}$

Stipendijní charakter měly i nadace a fondy, které vznikaly na základě přání zesnulých občanů. Tito lidé stanovili ve své závěti částku, z níž měla být nadace založena, po úmrtí dané osoby a po přečtení závěti byl sepsán nadační list, ve kterém byly obsaženy podmínky pro udělení úvěrů z nadační částky, tento list musel být schválen místodržitelstvím $\mathrm{v}$ Praze. Většina nadací byla pod správou městského zastupitelstva, jehož členové se v nadačním listu zavázali, že o ni budou pečovat a důchody z ní budou užívány, jak bylo nařízeno. Za účelem udělení nadace musel být vypsán konkurz, žadatelé museli předložit vysvědčení chudoby, křestní list, popřípadě školní nebo lékařské vysvědčení. Vše se řídilo podle toho, pro koho byla daná nadace určena. Městské zastupitelstvo bylo povinno vyšetřit výdělkové, rodinné a majetkové poměry žadatelů, muselo zjistit i poměry rodičů, pokud nějací existovali. ${ }^{4}$ V každém městě vznikalo mnoho nadací, velká část $\mathrm{z}$ nich byla určena chudým žákům místních škol. Zaměřovaly se nejen na školy městské a obecní, ale i na školy střední. Z nadací byly rozdělovány úroky z uložených peněz, a to vždy dvakrát do roka. Důležitou podmínkou pro udělení byla chudoba, píle a mravnost. ${ }^{5}$

Některé nadace byly zakládány při významných jubileích at' už panovnických, či školních. Vznikaly nadace, jejichž cílem byla pomoc získat chudým a nadaným absolventům střední školy další odborné vzdělání. ${ }^{6}$ Nadace byly zaměřeny většinou na studenty či žáky konkrétní školy, domovská př́slušnost $\mathrm{v}$ těchto prŕpadech nebyla podmínkou. Je možné nalézt i výjimky, kdy byla nadace zaměřena výlučně na chudé žáky pocházející z měšt’anských rodin, domovsky př́slušných $\mathrm{k}$ městu. ${ }^{7}$ Pokud se nadace zaměřovala na podporu studenta, bylo nutné, aby si po celou dobu této pomoci udržel dobrý prospěch a choval se mravně. Ještě

\footnotetext{
${ }^{2}$ KABLIK, Vincenz, 1850. Memorabilien der Stadt Pardubitz. Kroniky, rkp. 27, s. 630. SOkA Pardubice.

3 Spolek pro podporu nemajetných studujících reálné školy v Pardubicích, 1914. Zpráva o činnosti. OÚ Pardubice, kart. 489, inv. č. 781. SOkA Pardubice.

${ }^{4}$ Nadace a fondy, 1910-1914. OÚ Pardubice, kart. 258. SOkA Pardubice.

${ }^{5}$ Krausova nadace, Archiv města Pardubice (dále AM Pardubice), kart. 111. SOkA Pardubice.

${ }^{6}$ KABLIK, Vincenz, 1850. Memorabilien der Stadt Pardubitz. Kroniky, rkp. 27, s. 701. SOkA Pardubice.

${ }^{7}$ Nadace Jos. Benedettiho, OÚ Pardubice, kart. 82. SOkA Pardubice.
} 
v šedesátých letech 19. století nebyly nadace a fondy výlučně určeny pro studenty ovládající český nebo německý jazyk. V osmdesátých letech a na počátku 20. století už $53 \%$ nadací a $54 \%$ fondů bylo příslušností určeno konkrétní národnosti. Na počátku 20. století převažovaly nadace podmíněné pouze národnostními hledisky. Nestačilo už uvést, že nadace je určena pro českého studenta či pro studenta české techniky. Ustanovení muselo být doplněno klauzulí, že z jejího používání je vyloučen ten, kdo nestudoval nebo nematuroval na ústavu s českým vyučovacím jazykem. K podobným zásadám přistoupili i Němci (Pokorný, 1994, s. 2-3). Obdobný vývoj jako u nadací a fondů můžeme nalézt také u dobročinných spolků. Cílem sociální péče se stává záchrana dítěte pro národ a zabránění jeho odnárodnění (např. Červinková-Riegrová, 1894). Sociální péče byla vnímána jako prostředek integrace do národní společnosti (Urban, 1982, s. 264 an.) a vedla v jazykově smíšených lokalitách při zakládání dobročinných spolků k soutěži a ke sporům.

\section{Instituce dohlížející na děti a organizující mimoškolní činnosti}

Od 80. let 19. století vznikaly pro školní děti tzv. útulky. Jednalo se o výchovné ústavy pro školní mládež, do kterých se přijímaly školou povinné děti chudých rodičů, kteří chodili do zaměstnání. Cílem útulkủ bylo zabránit dětské potulce po ulicích a užitečně naplnit čas, což bylo chápáno jako důležitý prostředek proti delikvenci a kriminalitě mládeže. První útulky pro školou povinné děti byly založeny v Praze v roce 1886 na návrh Josefa Šauera z Augenburgu (Ottův slovník naučný, 1907, s. 264). Náklady na provoz pražských útulků byly hrazeny z obecního rozpočtu. Žáci v nich byli rozděleni podle pohlaví. Některé útulky se nacházely $\mathrm{v}$ pronajatých místnostech, ale většina byla zrrízena přímo ve školních budovách. Péčí o děti byly pověřeny vychovatelky působící při školách jako industriální učitelky. Děti byly v útulcích vychovávány, rovněž jim byla poskytována strava (Útulky, 1887, s. 155). Praha se stala vzorem v péči o školní mládež pro ostatní větší města. Útulky byly zřizovány například v Plzni, Ústí nad Labem, Pardubicích, Deštné nebo Kamenici nad Lipou.

Specifickou péči o starší děti nabízely besídky, s jejich zřizováním se setkáváme rovněž od 80. let 19. století. Některé fungovaly při školních budovách. V Praze existovaly tři besídky zřizované spolkem Družina blahoslavené Anežky České nacházející se při dívčích školách. Besídky byly otevřeny pouze v neděli a ve svátek. Dívky zde měly získat poučení a zábavu, pro účastnice byly pořádány výlety, divadelní představení nebo mikulášské zábavy. Družina blahoslavené Anežky České měla konfesionální charakter, byla určena pouze pro dívky katolického vyznání. Existovaly i besídky zaměřené na všechny dívky bez rozdílu vyznání, takové besídky zřizoval Ženský klub a Ústřední spolek českých žen v Praze (Ročenka, 1910, s. 28).

Podnětem pro rozšíření počtu besídek se stal oběžník ministerstva obchodu ze dne 27. října 1900 č. 50 811, v němž byla živnostenská společenstva upozorněna na důležitost zřizování besídek. Ministerstvo přislíbilo na provoz nových institucí finanční podporu. Besídky začaly zakládat spolky živnostenského a hospodářského charakteru. Úkolem besídek bylo shromažd'ovat učně v době jejich volna ( $v$ neděli, o svátcích i večer) k společnému pobytu podléhajícímu dozoru a doplňovat jejich společenskou a mravní výchovu - cílem bylo zabavit učně po celou dobu, kdy se nacházeli mimo dozor mistra, a bojovat tak proti kriminalitě 
a delikvenci. Besídky byly zrrizovány bud' samostatně, nebo společně s azyly určenými pro dlouhodobější pobyt. Některé se nacházely v budovách pokračovacích škol. Během pobytu v besídce museli prijatí dodržovat domácí řád. Jak v dívčích, tak chlapeckých besídkách byla př́isně kontrolována docházka, při neomluvené absenci hrozilo vyloučení, stejně jako při opakovaném nevhodném chování či neposlušnosti. O odezvě na oběžník svědčí počet vzniklých besídek, např. roku 1910 jich existovalo více než 60 (Schuster, 1903, s. 22 an.).

Specifickou podporu začaly školním dětem od 80. let nabízet spolky tzv. prázdninové péče, které byly zaměřeny výlučně na městské děti. Jejich cílem bylo zlepšit zdravotní stav dětí pobytem na venkově a současně zabránit delikvenci mládeže. Nejstarší spolky tohoto zaměření vznikly v Praze v roce 1882. Jednalo se o Spolek pro české feriální osady města Prahy a jeho predměstí a Verein für deutsche Ferien-Kolonien für arme und schwächliche Kinder der deutschen Schulen Prags und der Vororte. Děti do péče spolku navrhovaly jednotlivé školy. Před odjezdem do prázdninové kolonie byly děti lékařem prohlédnuty a zváženy. Spolky si pro prázdninovou péči pronajímaly nemovitosti na venkově nebo stavěly nové ústavy určené pro tuto péči. Např. český pražský spolek zřídil ústav v Luži, německý založil Kinderheilstäte v Dřevíči (Engliš, 1908, s. 103). Pobyt v kolonii trval dva až tři týdny. $\mathrm{V}$ denním programu činností, byl kladen velký důraz na pobyt $\mathrm{v}$ přírodě a pohybové aktivity. Během procházek měly děti pozorovat přírodu a učit se ji poznávat, zároveň jim učitelé dávali různé úkoly, jejichž cílem bylo zlepšit jejich manuální zručnost. Součástí výchovy bylo i opakování učební látky. Pro dospívající mládež byly organizovány v prázdninových koloniích speciální kurzy, které ji měly připravit na praktický život (Ochrana mládeže, ročník 5., sešit 4, 1915, s. 110-111).

\section{Závěrem}

Všechny výše popsané spolky, nadace a fondy fungovaly při školách. Je nutné zdůraznit, že existovaly i další dobročinné spolky zaměřené na školní děti a mládež, které nebyly vázané na konkrétní školu. Péče spolků se zaměřovala na děti normální, děti duševně nebo tělesně postižené, tzv. abnormální; na ty, které měly rodinu, ale žily ve špatných podmínkách, a na děti bez rodiny, týkala se zdravých a nemocných dětí (Čáda, 1916, s.7 n.). Způsob ochrany se u spolků lišil. Některé podporovaly děti finančně, jiné poskytovaly základní životní potřeby, další zakládaly ústavy určené pro pobyt a výchovu. Učitelé a učitelky byli členy dobročinných spolků. Pro statistické účely sepisovali seznamy dětí, které potřebovaly podporu. Jako členové spolku mohli provádět i kontrolní činnost v rodině podporovaného dítěte. Někdy sami iniciovali vznik podpůrné instituce nebo sbírky, která byla určena pro chudé. Ačkoliv se ve škole sociální péče nevykonávala přímo, školy se staly jejím důležitým centrem. Měly přehled o chudých a ohrožených dětech, sdružovaly se při nich spolky na podporu nemajetných, zároveň zde byly děti vedeny $\mathrm{k}$ dobročinnosti.

Většina spolků popsaných v tomto článku byla městského charakteru. Počet dětí podpořených v rámci jednoho roku závisel především na finančních prostředcích. Spolky získávaly peníze z členských příspěvků, také přijímaly finanční nebo věcné dary a pořádaly zábavné akce, jejichž výtěžek byl určen ve prospěch spolku. 
Od 80. let 19. století docházelo k nárůstu počtu dobročinných aktivit, do popředí se dostává národní charakter. Cílem většiny dobročinných iniciativ (at' českých, nebo německých) bylo zlepšit podmínky chudých dětí a prostřednictvím dohledu působit na jejich mravnost. Pouze mravný a národně vzdělaný jedinec představoval budoucnost. Existence dobročinných spolků zaměřených na děti a mládež svědčí o snaze měšt’anstva o disciplinaci nižších vrstev společnosti, představuje snahu o nápravu chudých rodin $\mathrm{v}$ rámci měšt’anského ideálu rodinného života.

\section{Literatura}

BĚLINA, Pavel, KAŠE, Jiří a KUČERA, Jan P., 2001. Velké dějiny zemí Koruny české. Sv. X. 1740-1792. Praha: Paseka. ISBN 80-7185-264-3.

BREZINKA, Wolfgang, 2015. Profesionalizace učitelského vzdělávání ve střední a jižní Evropě. In: KASPER, Tomáš et al. Učitel ve středni a jihovýchodni Evropě: profesionalizace učitelského vzdělávání: historické a systematické aspekty. Praha: Academia, s. 29-50. ISBN 978-80-200-2473-2; 978-80-86935-26.

ENGLIŠ, Karel, 1908. Zprávy Zemského statistického úr̆adu Království českého. Svazek XIII., Chudinství v Království českém na počátku XX. století. Vyd. české. V Praze: Zemský statistický úřad Království českého.

ČÁDA, František, 1916. Péče o děti a mládež. V Praze: [s.n.].

ČERVINKOVÁ-RIEGROVÁ, Marie, 1894. Ochrana chudé a opuštěné mládeže. V Praze: Nákladem spolku „Ochrana opuštěných a zanedbaných dívek“.

GRIMM Gerald, 2015. Učitelská prríprava v Rakousku mezi řemeslem / „výcvikem“ a vědeckým pojetím / profesionalizací (1774-1869). In: KASPER, Tomáš et al. Učitel ve středni a jihovýchodni Evropě: profesionalizace učitelského vzdělávání: historické a systematické aspekty. Praha: Academia, s. 51-64. ISBN 978-80-200-2473-2; 978-80-8693526.

HALÍř́VVÁ, Martina, 2012. Sociální patologie a ochrana dětství v Čechách od dob osvícenství do roku 1914: disciplinace jako součást ochrany dětství. Pardubice: Univerzita Pardubice, Fakulta filozofická (Monographica; 10). ISBN 978-80-7395-486-4.

HLAVAČKA, Milan, CIBULKA, Pavel, POKORNÝ, Jiří, FEJTOVÁ, Olga a BEK, Pavel, 2015. Sociální myšlení a sociální praxe v českých zemích 1781-1939: ideje, legislativa, instituce. Praha: Historický ústav (Práce Historického ústavu AV ČR = Opera Instituti Historici Pragae. Řada A, Monographia; 54). ISBN 978-80-7286-241-2.

KASPER, Tomáš a PÁNKOVÁ, Markéta, 2015. Učitel ve středni a jihovýchodní Evropě: profesionalizace učitelského vzdělávání: historické a systematické aspekty. Praha: Academia: Národní pedagogické muzeum a knihovna J. A. Komenského, 2015. ISBN 978-80-200-24732; 978-80-86935-26.

KASPER, Tomáš, 2015. Profesionalizace učitelského vzdělávání v českých zemích v pozdním osvícenství. In: KASPER, Tomáš a PÁNKOVÁ, Markéta, Učitel ve střední a jihovýchodní Evropě: profesionalizace učitelského vzdělávání: historické a systematické 
aspekty. Praha: Academia: Národní pedagogické muzeum a knihovna J. A. Komenského, s. 76-85.

LENDEROVÁ, Milena, HALÍŘOVÁ, Martina a JIRÁNEK, Tomáš, 2015. V̌se pro ditě: válečné dětství 1914-1918. Praha; Litomyšl: Paseka, 2015. ISBN 978-80-7432-499-4.

LENDEROVÁ, Milena, RÝDL, Karel, 2006. Radostné dětství?: dítě v Čechách devatenáctého století. V Praze; V Litomyšli: Paseka. ISBN 80-7185-647-9.

Ottův slovník naučný: illustrovaná encyklopaedie obecných vědomostí, 1907. XXVI díl. V Praze: J. Otto.

MORKES, František, 2004. Devětkrát o českém školství (přehledný průvodce). Praha: Pedagogické muzeum J. A. Komenského v Praze. ISBN 80-901461-6-3.

NOVOTNÝ, Miroslav, 2008. Děti státu. Školství v českých zemích mezi reformou a tradicí. In: Post tenebras spero lucem. Duchovní tvár̆ českého a moravského osvícenství. Praha: Casablanca, s. 148-163.

Ochrana mládeže: časopis pro veřejnou i soukromou péči o mládež v Královstvi českém, 1915. Ročník 5. sešit 4, Praha: Emil Šolc spol s r.o. v Karlíně, s. 110-111.

POKORNÝ, Jiří, 1994. Studijní nadání v království českém. In: Grant-průvodce po nadačním dění. 1994, roč. 2, č. 7, s. 2-3. ISSN 1210-6461.

Přklad Zákonníka řišského, vydaný pro království České. 1864. Ročník 1863. V Praze: Místodržitelská knihtiskárna.

Ročenka České zemské komise pro ochranu dítek a péči o mládež v království Českém, 1910. Část první. První rok činnosti České zemské komise. Praha: Česká zemská komise pro ochranu dítek a péči o mládež v král. Českém.

SCHUSTER, Václav, 1903. Útulky pro učně. Praha: nákladem zem. výboru království Českého.

ŠAFRÁNEK, Jan, 1897. Vývoj soustavy obecného školství v království českém od roku 1769-1895: Příspěvek k dějinám českého vyučování. Praha: F. Kytka.

ŠŤASTNÁ, Jarmila, 1977. Stravování pražského dělnictva a chudiny ve druhé polovině 19. a na počátku 20. století. Český lid 64, No. 1 (1977), s. 9-22.

TVRDOŇ, Antonín a ZEMAN, František, 1931. Péče o chudé a péče o mládež ochrany potřebnou $v$ republice Československé v roce 1931. Díl 2, veřejná ústavní a všeobecná dobrovolná péče o chudé a mládež ochrany potřebnou v republice Československé v roce 1931. Praha: Státní úřad statistický.

URBAN, Otto, 1982. Česká společnost 1848-1918. Praha: Svoboda.

Útulky pro chudou školní mládež. 1887. Administrativní zpráva Prahy a předměstí za rok 1885-1886. Praha: nákladem vlastním.

\section{Archivní prameny}

KABLIK, Vincenz, 1850. Memorabilien der Stadt Pardubitz. Kroniky, rkp 27, s. 630. Státní okresní archiv Pardubice (dále SOkA Pardubice).

Krausova nadace, Archiv města Pardubice (dále AM Pardubice), kart. 111. SOkA Pardubice.

Nadace Jos. Benedettiho, OÚ Pardubice, kart. 82. SOkA Pardubice. 
Nadace a fondy, 1910-1914. OÚ Pardubice, kart. 258. SOkA Pardubice.

Spolek pro podporu nemajetných studujících reálné školy v Pardubicích, 1914. Zpráva o činnosti. Okresní úřad Pardubice (dále OÚ Pardubice), kart. 489, inv. č. 781. SOkA Pardubice. 